\title{
Annual changes in the nutritive state of North Sea dab
}

\author{
R. SABOrowsKi AND F. BuchHOLZ \\ Biologische Anstalt Helgoland, Marine Station, D-27483 Helgoland, Germany
}

(Received 5 May 1995, Accepted 3 October 1995)

\begin{abstract}
The nutritive state of dab Limanda limanda was investigated over a 2-year period at a fixed sampling site northwest of Helgoland (German Bight, North Sea), with respect to feeding habits and the accumulation of biochemical storage products. Ophiuroids formed the main weight of food organisms $(50 \%)$ while polychaetes $(10 \%)$, molluscs and crustaceans $(<5 \%$ each) were less frequent. Feeding activity in males varied between summer and winter, while females fed more constantly. The condition factor and the hepatosomatic index showed characteristic seasonal cycles in both sexes. The glycogen content in the liver reached $40-60 \mathrm{mg} \mathrm{g}^{-1} \mathrm{FW}$ in summer and fell to about $10-20 \mathrm{mg} \mathrm{g}^{-1} \mathrm{FW}$ in late winter. Total lipids of the liver showed a distinct seasonal cycle with $400 \mathrm{mg} \mathrm{g}^{-1} \mathrm{FW}$ in summer and a minimum of $50-100 \mathrm{mg} \mathrm{g}^{-1} \mathrm{FW}$ in spring. The lipid content of the muscle ranged from 5 to $6 \mathrm{mg} \mathrm{g}^{-1} \mathrm{FW}$ and did not vary significantly between seasons.

(C) 1996 The Fisheries Society of the British Isles
\end{abstract}

Key words: dab; nutrition; season; glycogen; lipids.

\section{INTRODUCTION}

The dab Limanda limanda, is the most abundant flatfish species in the North Sea (Bohl, 1957; Lozán, 1988; Daan et al., 1990) and therefore of significance in ecological processes. Dab stand on a high trophic level as predators on benthic organisms and are opportunistic in food selection (Franz, 1910; Kühl, 1963; Arntz, 1971). A number of studies have been carried out on the feeding habits of dab. However, investigations of nutrient accumulation in relation to feeding habits have not been carried out so far.

In order to cover the energy demand for the winter, which also is the period of gonad maturation, individuals have to store nutrients during the productive summer season. Lipids, preferably accumulated in the liver and the muscle tissue, are particularly important for energy storage and energy production due to their high calorific value. Furthermore, lipids act as carriers for non-water soluble nutrients, e.g. vitamins A, D and E. However, due to progressing marine pollution, lipophilic xenobiotics (e.g. PCBs and oil residues) accumulate along the trophic chain. Accordingly, elevated concentrations of pollutants were determined in different tissues and particularly in the liver of dab (Dethlefsen \& Huschenbeth, 1986; Knickmeyer \& Steinhart, 1989; Büther, 1990; Kammann et al., 1990).

To establish a basis for a better understanding and prediction of such accumulation processes, information is required on the natural course of lipid storage and lipid mobilization. This is particularly true for dab, which is considered to be a suitable tool for ecotoxicological investigations (Stebbing et al., 1992). 
In the present study we determined the annual profile of nutrient accumulation in relation to feeding habits of dab. Investigations were performed at a fixed station in the southern North Sea over a 2-year period. This study deals primarily with the physiology of nutrition, but some aspects of toxin accumulation are also discussed.

\section{MATERIAL AND METHODS}

\section{SAMPLES}

Dab were caught northwest of Helgoland $\left(54^{\circ} 15^{\prime} \mathrm{N}, 7^{\circ} 45^{\prime} \mathrm{E}\right)$ at a depth of $25-30 \mathrm{~m}$. Medium-sized specimens were selected randomly from catches which were obtained from the research vessel FK Uthörn and FS Heincke by bottom trawling. Sampling was carried out monthly from January 1993 to March 1994 and thereafter approximately every 6 weeks until November 1994. The length and the sex of the fish was determined immediately after capture. The animals were killed and the liver was excised quickly, freeze clamped in liquid nitrogen and stored at $-80^{\circ} \mathrm{C}$ for biochemical analysis. The fish were stored on ice during the transfer to the laboratory, where the weights of the liver and the digestive tract (stomach and gut) were determined. Muscle samples were excised from the middle of the dorsal side of the fish and were stored frozen at $-80^{\circ} \mathrm{C}$ until analysis.

\section{CONDITION FACTOR, STOMACH-GUT INDEX AND HEPATOSOMATIC INDEX}

The condition factor $(\mathrm{CF})$ was calculated in relation to the total weight $(W)$ and length $(L)$ :

$$
\mathrm{CF}=W \times 100 \times L^{-3} .
$$

As an index for the food ingested, the weight of the stomach and gut $\left(W_{s}\right)$ was calculated in relation to the carcass weight $\left(W_{c}\right)$, which represents the total weight minus the weight of the intestines (gonads, liver, stomach and gut), and expressed as stomachgut index (SGI):

$$
\mathrm{SGI}=W_{s} \times 100 \times W_{c}^{-1} .
$$

Correspondingly, the relative weight of the liver $\left(W_{l}\right)$ was calculated and expressed as the hepatosomatic index (HSI):

$$
\mathrm{HSI}=W_{l} \times 100 \times W_{c}^{-1}
$$

\section{STOMACH CONTENT}

The food organisms in the stomachs were classified into seven major groups: ophiuroids, polychaetes, molluscs, crustaceans, echinoids, fish and 'not identified'. The weight of the stomach content was determined in each fish. If different groups of food organisms were found within one stomach, the relative amount of each group was estimated. The sum of the weight of each group was calculated in relation to the sum of the stomach content of all fishes of the respective sampling day and expressed as a percentage of the total stomach content per sex.

\section{BIOCHEMICAL INVESTIGATIONS}

Since fish liver can show variability in biochemical parameters within different parts of the organ (Koprivnjak et al., 1996), we homogenized the whole liver in liquid nitrogen by pestle and mortar and performed the analysis on the resulting powder.

Glucose and glycogen determinations were carried out according to the methods of Kunst et al. (1984) and Keppler \& Decker (1984), respectively, and modified for use in microplate-readers. Frozen tissue powder $(20-50 \mathrm{mg})$ was homogenized in $1 \mathrm{ml}$ distilled 
water by ultrasonication (Branson Sonifier B12, microstic 101-148-063). The samples were sonicated on ice in reaction tubes (Eppendorf 3810) for $3 \times 2 \mathrm{~s}$ at $30 \%$ of maximum power. Immediately after homogenizing, the extract was heated for $10 \mathrm{~min}$ in a bath with boiling water to denature glycogen degrading enzymes. Subsamples of $250 \mu 1$ each were taken for glycogen and glucose determination. The subsample for glycogen determination was incubated in $500 \mu \mathrm{l}$ of $0.1 \mathrm{M}$ acetate buffer, $\mathrm{pH} 4.8$ and $20 \mu \mathrm{l}$ of amyloglucosidase $\left(1 \mathrm{mg} \mathrm{ml}^{-1}\right.$, Böhringer, No. 102857) for $2 \mathrm{~h}$ at $40^{\circ} \mathrm{C}$ to hydrolyse glycogen to glucose. Both subsamples were centrifuged for $10 \mathrm{~min}$ at $15000 \mathrm{~g}\left(4^{\circ} \mathrm{C}\right)$. The supernatants were used for the determination of glucose with the commercial test kit glucose UV test (Böhringer, No. 716251). Twenty $\mu 1$ of sample and $300 \mu 1$ of buffer solution (solution 1 of the test kit) were transferred into microplates. Prior to the hexokinase reaction the plate was read as blank at $340 \mathrm{~nm}$ with a Dynatech MR 7000 microplate reader. Hexokinase suspension $(20 \mu \mathrm{l}$ of a $1: 5$ dilution in A. dest) was added and the plate was incubated for $30 \mathrm{~min}$ at room temperature. The optical density (OD) at $340 \mathrm{~nm}$ was read again and the previously read blanks were subtracted from the results. Samples for glucose and glycogen were run in triplicate. Standards were run in parallel with $0,2 \cdot 5,5,7 \cdot 5$ and $10 \mu \mathrm{g}$ of glucose.

Total lipids were determined by the sulphophospho-vanillin method according to Zöllner \& Kirsch (1962). A commercial test kit (Merck, 3321) was adapted for the measurement in microplates. The lipid extraction of liver tissue was performed in $1.5 \mathrm{ml}$ reaction tubes. One $\mathrm{ml}$ of a chloroform : methanol solution $(1: 2 \mathrm{v} / \mathrm{v})$ was added to $20-50 \mathrm{mg}$ of mortared tissue. The tubes were sonicated in a water bath until a homogeneous suspension of the sample was observed. The samples were allowed to stay at room temperature for $30 \mathrm{~min}$ and thereafter were centrifuged for $10 \mathrm{~min}$ at $15000 \mathrm{~g}$. Fifty $\mu 1$ of the supernatants were transferred into glass reaction tubes and evaporated to dryness. Two $\mathrm{ml}$ of concentrated sulphuric acid were added into the reaction tubes and incubated for $10 \mathrm{~min}$ in a $100^{\circ} \mathrm{C}$ water bath. After cooling to room temperature, $20 \mu \mathrm{l}$ of this solution were transferred into microplates. A blank plate was prepared whilst $300 \mu 1$ of phosphoric acid $(11.8 \mathrm{M})$ were added to the samples and the OD was read at $530 \mathrm{~nm}$. The values of the blank plate were subtracted from the sample plate, which was incubated for $2 \mathrm{~h}$ with $300 \mu \mathrm{l}$ of phospho-vanillin reagent. Standards of $0,100,200,300,400$ and $500 \mu \mathrm{g}$ lipid were processed as for the samples and run in parallel. This procedure allowed the determination of less than $50 \mu \mathrm{g}$ of total lipid and proved suitable for the analysis of $\mathrm{mg}$ quantities of sample.

Total lipids of muscle tissue $(50-100 \mathrm{mg})$ were extracted and analysed as described for liver tissue. However, the extraction period was extended to $16 \mathrm{~h}$ and, after centrifugation $(15000 \mathrm{~g}, 10 \mathrm{~min}), 500 \mu \mathrm{l}$ of the supernatant were transferred into glass reaction tubes and evaporated to dryness.

\section{STATISTICS}

The data sets were analysed for normal distribution with the Kolmogorov-Smirnov test. When normal distribution failed or the number of observations was low $(n<12)$, non-parametric test methods were used for statistical analysis. Multiple comparison of data sets was performed with the Kruskal-Wallis analysis of variance on ranks (H-test) followed by Dunn's multiple comparison procedure. Pairwise comparison was carried out by using the Mann-Whitney rank order test (U-test) (Sachs, 1984). The data were presented in tables and graphs as median and first and third quartiles (1.Q, 3.Q) as error bars.

Non-linear regression was performed with the program 'Prism' (GraphPad Inc., San Diego). A sine function with the general formula

$$
y=\text { baseline }+ \text { amplitude } \times \sin (\text { frequency } \times x+\text { phaseshift })
$$

was fitted to the seasonal cycles of the investigated parameters. The goodness of the fit was represented by the correlation coefficient $(r)$. Differences of the baselines and amplitudes between sexes were considered significant when the $95 \%$ CI of the fits did not overlap. In one case (SGI of females), an outlier was excluded from statistical analysis 
which was identified by the Dixon's test at the 95\% confidence level (Sokal \& Rohlf, $1995 a, b)$. The concomitance of the seasonal cycles was investigated by rank correlation and characterized by the Spearman's rank correlation coefficient $\left(r_{s}\right)$. Because of the autocorrelation of the data, significance was approximated with the Bartlett method described by Lienert (1978). However, due to the relatively low number of data points the results were ambiguous in some cases. Therefore, we refrained from presenting significance levels in the respective tables and recommend that the degree of coherence be estimated by the correlation coefficient.

\section{RESULTS}

\section{LENGTH AND WEIGHT}

Slight differences in the length of investigated specimens appeared between the sampling times (Table I). During winter the number of males was often low; in these cases, smaller males were taken also. Generally, females were $1-2 \mathrm{~cm}$ larger than males. The median lengths ranged in females from 19.5 to $23.5 \mathrm{~cm}$ and in males from $17 \cdot 0$ to $21.5 \mathrm{~cm}$. A parallel detailed study on the population structure was carried out by Saborowski \& Buchholz (1996).

\section{STOMACH CONTENT AND FOOD ORGANISMS}

The median stomach content in females reached about $1 \mathrm{~g}$ (Fig. 1). Maximal values were found occasionally with $12-15 \mathrm{~g}$ of ingested food. No distinct seasonal pattern of ingested food was found in females and significant differences $(P<0 \cdot 05)$ appeared only between January 1993 and March 1994.

In males, the median stomach contents were slightly lower, reaching maximal values of $0.75 \mathrm{~g}$. In contrast to females, males exhibited a seasonal pattern of feeding activity, showing significantly lower stomach contents in winter compared to summer and early fall (e.g. June 1993 differed from February, March 1993 and January 1994, $P<0 \cdot 05)$.

The number of totally empty stomachs reflected a seasonal feeding pattern (Fig. 2). Most individuals with empty stomachs were found in winter and early spring, while in summer most stomachs were at least partly filled.

The main food organisms in both sexes were ophiuroids, representing about $50 \%$ by weight of the average stomach content over the entire period of investigation (Fig. 3). In each sex, the amount of ophiuroids was significantly higher $(P<0.05)$ than the amount of any other prey. Polychaetes formed $13 \%$ of the food in females and $8 \%$ in males while molluscs and crustaceans comprised less than 5\%. Occasionally, echinoids were found which, when present, reached a relatively large amount in the stomach of the individuals. Fish carrion was observed occasionally also and dominated the individual stomach contents when present. Unidentified food consisted mostly of strongly digested organisms or occasionally mud and sediment.

No significant differences between the sexes appeared in the preference for each group of prey (Fig. 3, P>0.05, U-test) nor was a distinct preference evident for a particular food source in either sex in the seasonal course (Fig. 4). Ophiuroids were always present in females and were only occasionally absent in males. Molluscs and crustaceans, however, were ingested by females predominantly in the summer of 1993 while males established a slight preference for crustaceans in the winter of 1993/1994. 
TABLE I. Sampling date, number $(n)$, length and weight of investigated animals $(\mathrm{m}=$ male, $\mathrm{f}=$ female)

\begin{tabular}{|c|c|c|c|c|c|c|c|c|}
\hline \multirow{2}{*}{$\begin{array}{l}\text { Date of } \\
\text { sampling }\end{array}$} & \multirow{2}{*}{ Sex } & \multirow{2}{*}{$n$} & \multicolumn{3}{|c|}{ Length $(\mathrm{cm})$} & \multicolumn{3}{|c|}{ Weight (g) } \\
\hline & & & Median & $1 . \mathrm{Q}$ & $3 . Q$ & Median & $1 . \mathrm{Q}$ & 3.Q \\
\hline \multirow[t]{2}{*}{28 Jan. 1993} & $\mathrm{f}$ & 13 & $22 \cdot 3$ & $21 \cdot 5$ & $23 \cdot 0$ & $115 \cdot 7$ & $101 \cdot 4$ & $128 \cdot 5$ \\
\hline & $\mathrm{m}$ & 11 & $17 \cdot 0$ & $16 \cdot 6$ & $17 \cdot 9$ & $44 \cdot 1$ & $41 \cdot 2$ & $50 \cdot 9$ \\
\hline \multirow[t]{2}{*}{16 Feb. 1993} & $\mathrm{f}$ & 12 & $22 \cdot 0$ & $21 \cdot 0$ & $23 \cdot 0$ & $111 \cdot 3$ & $90 \cdot 8$ & $133 \cdot 5$ \\
\hline & $\mathrm{m}$ & 12 & $17 \cdot 3$ & $15 \cdot 5$ & $19 \cdot 7$ & $45 \cdot 2$ & $38 \cdot 4$ & $69 \cdot 1$ \\
\hline \multirow[t]{2}{*}{18 Mar. 1993} & $\mathrm{f}$ & 12 & $20 \cdot 0$ & $18 \cdot 8$ & $21 \cdot 5$ & $77 \cdot 4$ & $61 \cdot 5$ & $94 \cdot 2$ \\
\hline & $\mathrm{m}$ & 12 & $19 \cdot 8$ & $18 \cdot 8$ & $20 \cdot 0$ & $68 \cdot 0$ & $59 \cdot 9$ & $73 \cdot 7$ \\
\hline \multirow[t]{2}{*}{7 Apr. 1993} & $\mathrm{f}$ & 12 & $21 \cdot 8$ & $19 \cdot 8$ & $22 \cdot 0$ & $85 \cdot 3$ & $78 \cdot 2$ & $112 \cdot 6$ \\
\hline & $\mathrm{m}$ & 12 & $18 \cdot 0$ & $17 \cdot 5$ & $19 \cdot 3$ & $54 \cdot 9$ & $46 \cdot 4$ & $66 \cdot 8$ \\
\hline \multirow[t]{2}{*}{14 May 1993} & f & 12 & $21 \cdot 0$ & $20 \cdot 3$ & $23 \cdot 5$ & $91 \cdot 0$ & $80 \cdot 2$ & $116 \cdot 3$ \\
\hline & $\mathrm{m}$ & 12 & $19 \cdot 0$ & $18 \cdot 3$ & $20 \cdot 0$ & $69 \cdot 4$ & $56 \cdot 7$ & $77 \cdot 8$ \\
\hline \multirow[t]{2}{*}{14 Jun. 1993} & f & 12 & $20 \cdot 0$ & $19 \cdot 5$ & $22 \cdot 0$ & $79 \cdot 9$ & $74 \cdot 0$ & $105 \cdot 9$ \\
\hline & $\mathrm{m}$ & 12 & $19 \cdot 0$ & $18 \cdot 0$ & $20 \cdot 0$ & $64 \cdot 0$ & $57 \cdot 7$ & $81 \cdot 3$ \\
\hline \multirow[t]{2}{*}{16 Jul. 1993} & f & 11 & $20 \cdot 0$ & $19 \cdot 1$ & $21 \cdot 5$ & $79 \cdot 4$ & $69 \cdot 6$ & $105 \cdot 0$ \\
\hline & $\mathrm{m}$ & 12 & $18 \cdot 8$ & $18 \cdot 3$ & $19 \cdot 5$ & $68 \cdot 3$ & $63 \cdot 1$ & $81 \cdot 7$ \\
\hline \multirow[t]{2}{*}{27 Aug. 1993} & $\mathrm{f}$ & 11 & $20 \cdot 5$ & $19 \cdot 1$ & $22 \cdot 4$ & $88 \cdot 0$ & $72 \cdot 1$ & $111 \cdot 0$ \\
\hline & $\mathrm{m}$ & 12 & $20 \cdot 0$ & $18 \cdot 5$ & $21 \cdot 1$ & $84 \cdot 4$ & $67 \cdot 2$ & $96 \cdot 7$ \\
\hline \multirow[t]{2}{*}{22 Sep. 1993} & $\mathrm{f}$ & 13 & $20 \cdot 0$ & $19 \cdot 9$ & $22 \cdot 0$ & $89 \cdot 7$ & $79 \cdot 6$ & $113 \cdot 7$ \\
\hline & $\mathrm{m}$ & 11 & $20 \cdot 0$ & $19 \cdot 0$ & $20 \cdot 9$ & $78 \cdot 0$ & $73 \cdot 5$ & $91 \cdot 1$ \\
\hline \multirow[t]{2}{*}{14 Oct. 1993} & $\mathrm{f}$ & 12 & $22 \cdot 3$ & $21 \cdot 0$ & $24 \cdot 3$ & $104 \cdot 4$ & $92 \cdot 4$ & $153 \cdot 2$ \\
\hline & $\mathrm{m}$ & 12 & $20 \cdot 3$ & $19 \cdot 8$ & $21 \cdot 8$ & $92 \cdot 6$ & $82 \cdot 8$ & $109 \cdot 1$ \\
\hline \multirow[t]{2}{*}{16 Nov. 1993} & $\mathrm{f}$ & 12 & $22 \cdot 8$ & $22 \cdot 3$ & $23 \cdot 0$ & $117 \cdot 5$ & $114 \cdot 0$ & $134 \cdot 1$ \\
\hline & $\mathrm{m}$ & 12 & $17 \cdot 8$ & $17 \cdot 0$ & $20 \cdot 3$ & $61 \cdot 5$ & $50 \cdot 0$ & $80 \cdot 2$ \\
\hline \multirow[t]{2}{*}{4 Jan. 1994} & $\mathrm{f}$ & 12 & $20 \cdot 0$ & $19 \cdot 0$ & $21 \cdot 0$ & $90 \cdot 1$ & $70 \cdot 6$ & $97 \cdot 2$ \\
\hline & $\mathrm{m}$ & 8 & $18 \cdot 3$ & $16 \cdot 5$ & $19 \cdot 5$ & $55 \cdot 8$ & $46 \cdot 2$ & $66 \cdot 5$ \\
\hline \multirow[t]{2}{*}{10 Feb. 1994} & $\mathrm{f}$ & 12 & $21 \cdot 5$ & $20 \cdot 5$ & $22 \cdot 3$ & $116 \cdot 1$ & $86 \cdot 8$ & $134 \cdot 8$ \\
\hline & $\mathrm{m}$ & 6 & $18 \cdot 0$ & $17 \cdot 0$ & $19 \cdot 0$ & $50 \cdot 0$ & $43 \cdot 1$ & $52 \cdot 9$ \\
\hline \multirow[t]{2}{*}{17 Mar. 1994} & $\mathrm{f}$ & 12 & $19 \cdot 5$ & $18 \cdot 5$ & $20 \cdot 0$ & $72 \cdot 0$ & $59 \cdot 3$ & $79 \cdot 3$ \\
\hline & $\mathrm{m}$ & 8 & $16 \cdot 8$ & $16 \cdot 5$ & $18 \cdot 0$ & $43 \cdot 3$ & $37 \cdot 0$ & $54 \cdot 9$ \\
\hline \multirow[t]{2}{*}{5 May 1994} & $\mathrm{f}$ & 11 & $23 \cdot 0$ & $22 \cdot 5$ & $24 \cdot 3$ & $110 \cdot 2$ & $96 \cdot 9$ & $131 \cdot 0$ \\
\hline & $\mathrm{m}$ & 13 & $20 \cdot 5$ & $20 \cdot 0$ & $22 \cdot 1$ & $78 \cdot 9$ & $74 \cdot 7$ & $89 \cdot 2$ \\
\hline \multirow[t]{2}{*}{16 Jun. 1994} & $\mathrm{f}$ & 12 & $22 \cdot 8$ & $22 \cdot 0$ & $24 \cdot 3$ & $122 \cdot 0$ & $108 \cdot 6$ & $130 \cdot 2$ \\
\hline & $\mathrm{m}$ & 12 & $20 \cdot 8$ & $20 \cdot 3$ & $21 \cdot 5$ & 83.8 & $78 \cdot 2$ & $92 \cdot 4$ \\
\hline \multirow[t]{2}{*}{27 Jul. 1994} & $\mathrm{f}$ & 12 & $23 \cdot 5$ & $21 \cdot 3$ & $24 \cdot 3$ & $114 \cdot 4$ & $99 \cdot 2$ & $144 \cdot 4$ \\
\hline & $\mathrm{m}$ & 12 & $21 \cdot 0$ & $20 \cdot 0$ & $22 \cdot 8$ & $96 \cdot 7$ & $86 \cdot 8$ & $107 \cdot 4$ \\
\hline \multirow[t]{2}{*}{8 Sep. 1994} & f & 12 & $20 \cdot 5$ & $20 \cdot 0$ & $21 \cdot 8$ & $89 \cdot 8$ & $84 \cdot 3$ & $108 \cdot 7$ \\
\hline & $\mathrm{m}$ & 12 & $20 \cdot 5$ & $20 \cdot 0$ & $21 \cdot 5$ & $90 \cdot 4$ & $80 \cdot 5$ & $100 \cdot 0$ \\
\hline \multirow[t]{2}{*}{4 Nov. 1994} & $\mathrm{f}$ & 12 & $21 \cdot 5$ & $21 \cdot 0$ & $22 \cdot 8$ & $106 \cdot 1$ & $97 \cdot 6$ & $116 \cdot 1$ \\
\hline & $\mathrm{m}$ & 12 & $21 \cdot 3$ & $20 \cdot 3$ & $21 \cdot 8$ & $93 \cdot 1$ & $83 \cdot 1$ & $103 \cdot 8$ \\
\hline
\end{tabular}

Similarities in the seasonal feeding regime of the sexes were determined by rank correlation of the monthly medians of the amounts of prey organisms. No correlation was found in the case of polychaetes and molluscs (Table II). In contrast, ophiuroids and unidentified material were ingested by both sexes in a proportional amount while the amounts of crustaceans were inversely correlated. The highest correlation coefficient was found in echinoids which, however, was based on only a few observations. 


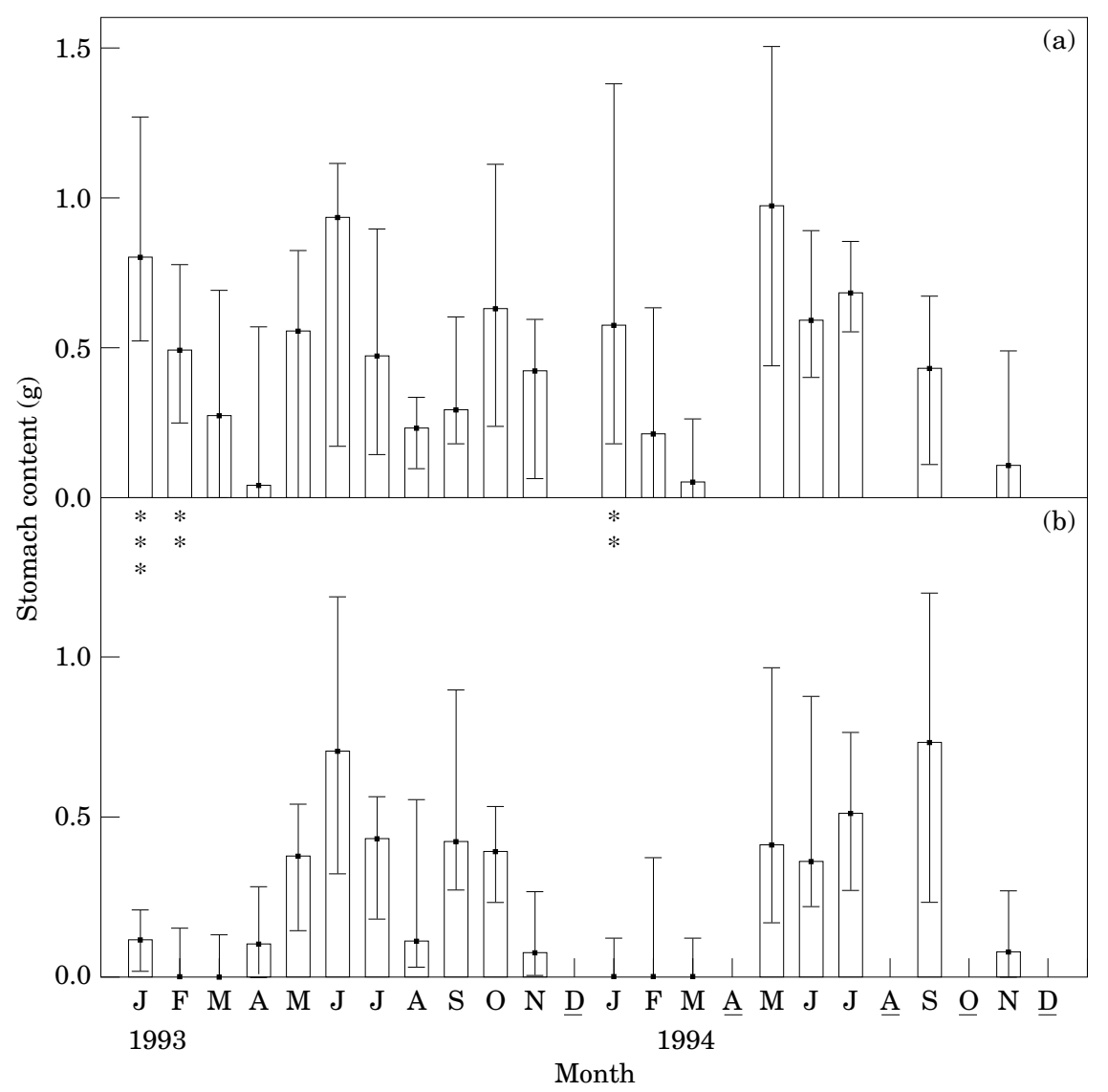

FIG. 1. Stomach content of (a) female and (b) male dab (median, 1.Q, 3.Q, $n=6-13$ ). No sampling was carried out in months underlined. Asterisks indicate significant differences between the sexes at the respective sampling time $\left({ }^{*} P<0 \cdot 05 ; * * P<0 \cdot 01 ; * * * P<0 \cdot 001\right)$.

\section{STOMACH-GUT INDEX}

The stomach gut index (SGI) represented a value for the total ingested food [Fig. 5(a)]. The seasonal course was fitted to a sine function which matched significantly in both sexes. The strongly elevated SGI in females of May 1994 was excluded from the regression because it was identified as an outlier (Dixon's test). High variability between the sampling periods was observed in winter and spring of 1993, while in the following year the data points corresponded more closely with the sine curve fitted.

In females, the highest values (6-8) were found during the summer and the lowest winter values ranged from 4 to 6 . In 1993, significant differences $(P<0 \cdot 05)$ were determined between January and March as well as between January and June. In 1994, no significant differences appeared when the sampling periods were compared with the exception of the extreme values of May, which were significantly higher than in February, March and November 1994.

In males, highest values were similar to those in females and ranged from 6.0 to 6.5 in summer. Lowest values ranged from 3.5 to 4.0 in winter. An extremely 


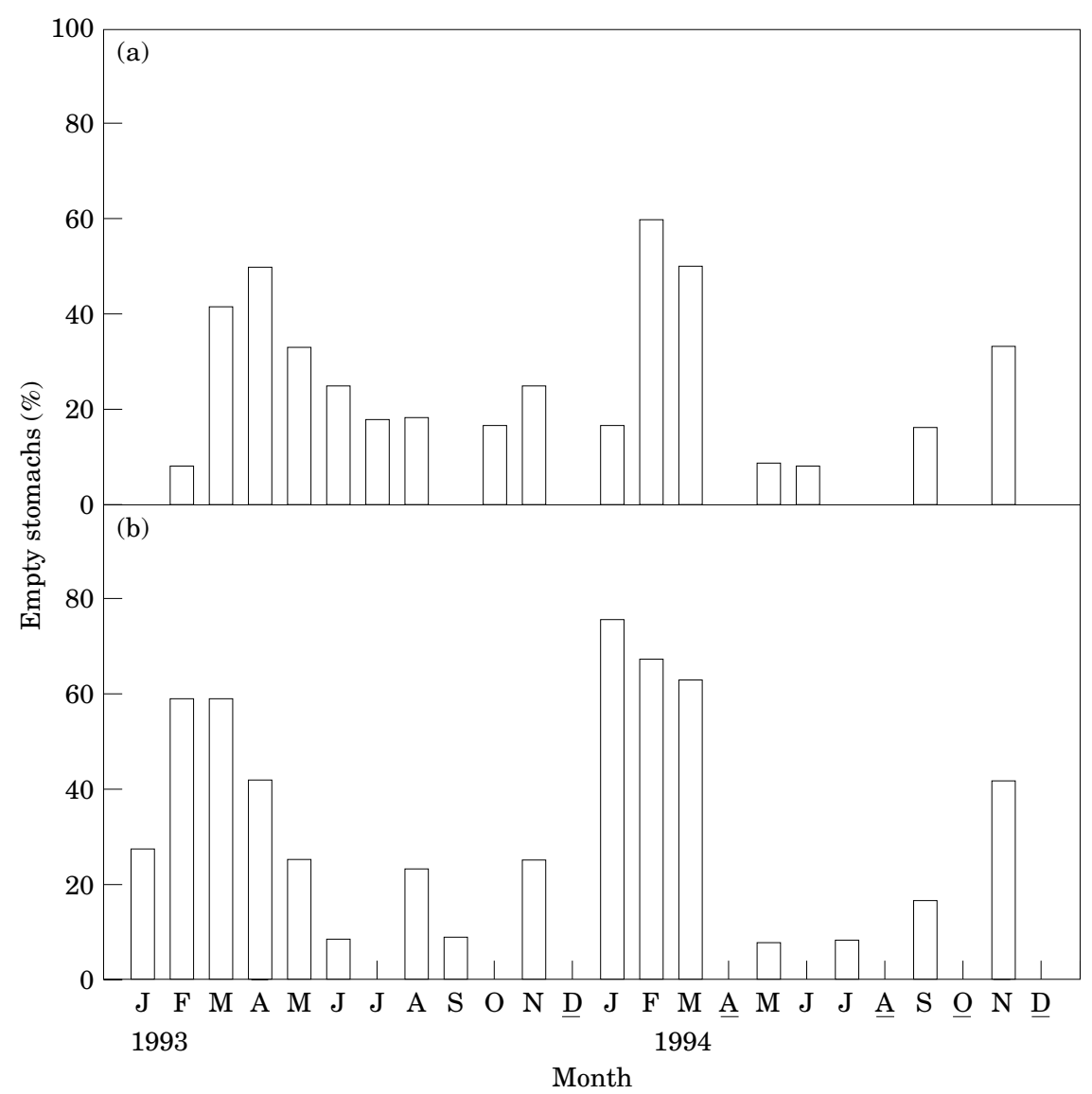

FIG. 2. Percentage of empty stomachs in (a) female dab and (b) male dab. No sampling was carried out in months underlined.

low value was determined in January 1993. In 1993, the values of January and November were significantly lower than the SGIs of May, June, July and September. Furthermore, January differed significantly from August. In 1994, no significant differences were evident between the sampling times.

The amplitude of the sine curve calculated varied from $5 \cdot 3$ to $7 \cdot 0$ in females and 3.3 to 6.9 in males. The spans were 1.7 in females and 3.6 in males. Due to the high variability of the data the spans did not differ significantly. However, the baselines were significantly different between the sexes $(6 \cdot 2$ in females and $5 \cdot 1$ in males). No distinct phase-shift appeared between the curves. Significant differences between the sexes (U-test) dominated during the winter.

\section{CONDITION FACTORS}

The condition factor (CF) followed a seasonal cycle and in both sexes significantly matched the sine curve fitted [Fig. 5(b)]. In winter, however, some of the female CFs diverged due to gonad maturation (January, February 1993 and February 1994) and therefore were excluded from the regression. 


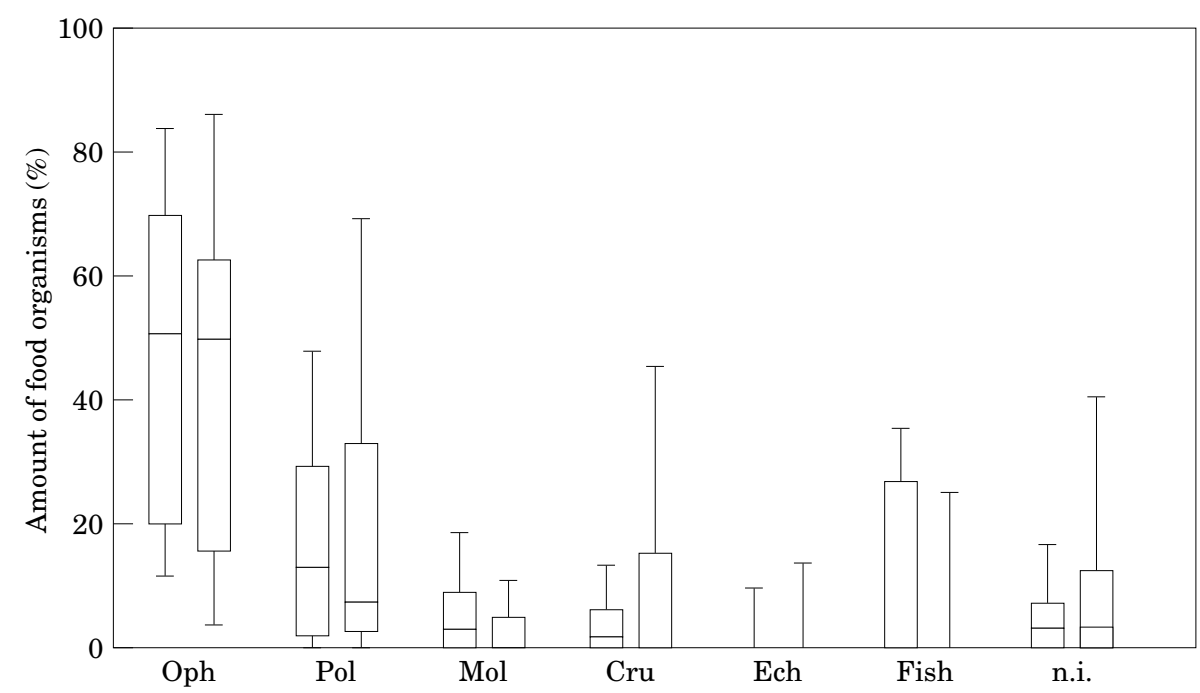

FIG. 3. Relative amount of food organisms (main taxa) averaged from all monthly observations during the study $(n=19)$. Abbreviations as Table II; females: left box; males: right box.

In females, the maximum values of $1 \cdot 05-1 \cdot 1$ were observed in autumn (October/November) and the minimum of 0.90-0.95 appeared in spring (April/ May).

Significant differences between the sampling periods $(P<0 \cdot 05)$ appeared between May 1994 and November to February of each year. Furthermore, the CF of February 1994 was significantly higher than in May 1993.

In males, maximal values of about 1.05 were determined in late summer (August/September), while lowest values appeared in late winter (February/ March). In 1993, the CFs of January and March differed significantly from those of July to October, and April differed from October. In 1994, the CF of February was significantly lower than in July and September.

The calculated span of the sine regression ranged from 0.93 to 1.06 in females and was slightly lower than in males $(0.90-1 \cdot 06)$. The baselines were 0.995 in females and 0.980 in males, and did not differ significantly. A phase shift of the $\mathrm{CF}$ of about 2 months appeared when the sexes were compared. Significant differences between the sexes $(P<0 \cdot 05$, U-test $)$ were found during the winter [Fig. 5(b)].

\section{HEPATOSOMATIC INDEX (HSI)}

In both sexes, the seasonal course of the HSI followed closely the sine curve fitted [Fig. 5(c)]. Maximum HSIs of 3.0 appeared in early winter (December/ January) and the minimum (1.7-2.0) was found in early summer (May to July).

In 1993, the HSIs of February differed from those of May to August. The HSI of March was significantly higher than in June and July and the HSI of November exceeded that of June. In 1994, the HSIs of January and February were significantly higher than those of May and June. Additionally, February values exceeded the July and November values $(P<0 \cdot 05)$.

In males, the maximum values of $2 \cdot 0-2 \cdot 5$ were reached in late summer and the minima $(1 \cdot 0-1 \cdot 5)$ were determined in late winter. 


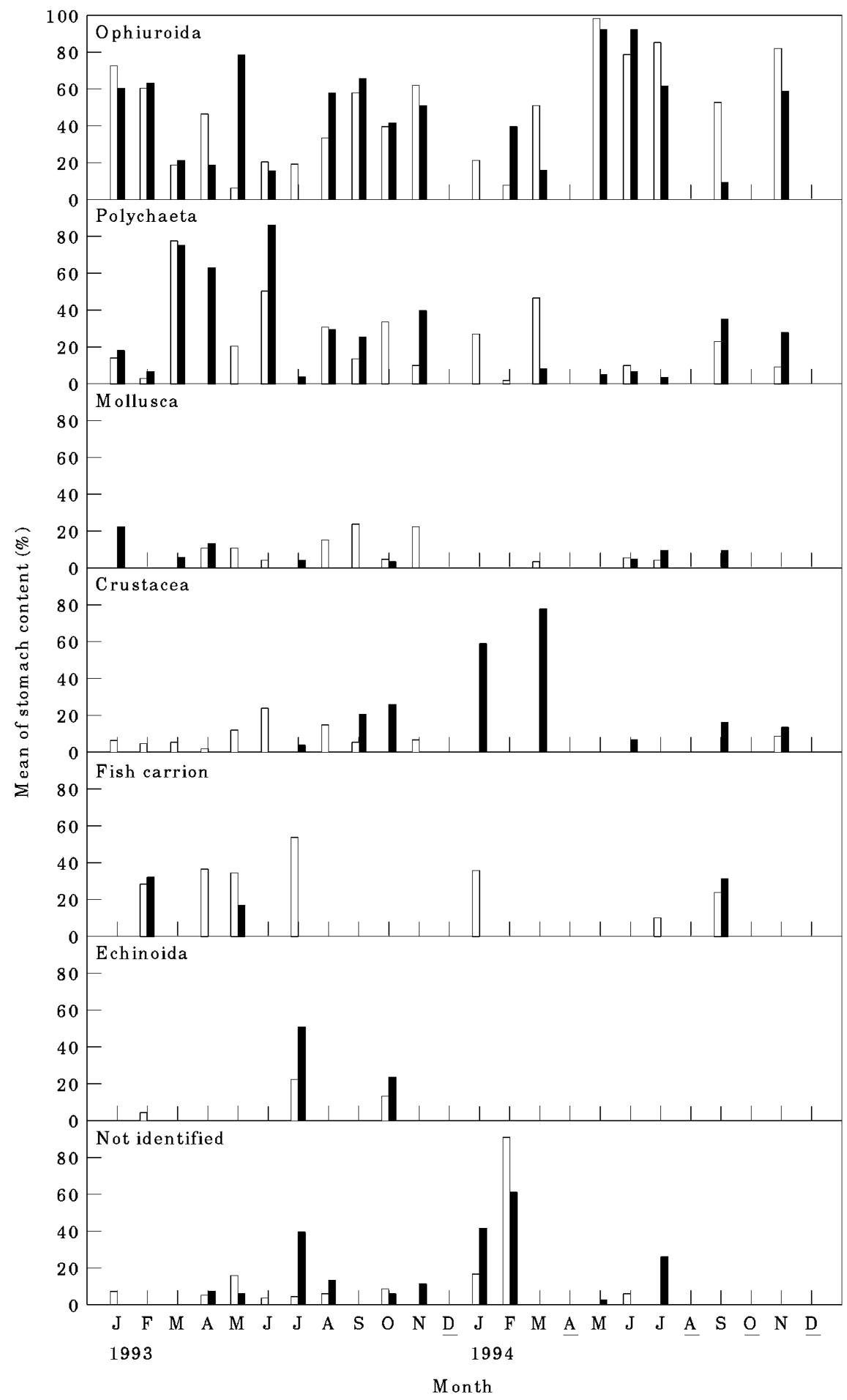

FIG. 4. Seasonal variation of food organisms in the stomach of female ( $\square$ ) and male ( $\square$ ) dab. Each group was expressed as percentage of the total stomach content of the catch per sex and per sampling time. No sampling was carried out in underlined months. 
TABLE II. Concomitance of prey organisms between females and males expressed by rank correlation coefficients $\left(r_{s}, n=19\right)$

\begin{tabular}{lcr}
\hline Parameter & Abbreviation & \multicolumn{1}{c}{$r_{s}$} \\
\hline Ophiuroids & Oph & 0.528 \\
Polychaetes & Pol & 0.283 \\
Molluscs & Mol & -0.010 \\
Crustaceans & Cru & -0.458 \\
Fish carrion & Fish & 0.452 \\
Echinoids & Ech & 0.840 \\
Not identified & n.i. & 0.504 \\
\hline
\end{tabular}

In 1993, the HSIs of August and September differed significantly from those of January, March, April and May. October values were significantly higher than those of March and April.

Based on the sine curve calculated, the HSI of females varied between 1.75 and 3.0. The HSI of males ranged from $1 \cdot 25$ to $2 \cdot 4$. Accordingly, the span between the maximum and the minimum of females was slightly higher $(1 \cdot 25)$ than that of males $(1 \cdot 18)$. However, this difference was not significant since the $95 \% \mathrm{CI}$ overlapped. In contrast, the baseline of the HSI of females (2.52) was significantly higher than that of males (1.82). A phase-shift of about 3 months was evident between the sexes and significant sexual differences $(P<0 \cdot 05$, U-test $)$ appeared predominantly during winter and spring [Fig. 5(c)].

\section{GLUCOSE}

The concentrations of free glucose in the liver did not follow a distinct seasonal pattern and therefore could not be fitted to a sine function [Fig. 6(a)]. The amount of glucose ranged from 1.2 to $5.4 \mathrm{mg} \mathrm{g}^{-1} \mathrm{FW}$. Particularly between January and May 1993 distinct short-term variations appeared and temporal glucose peaks were determined in February and May and June, respectively. During autumn and winter, the glucose concentrations remained relatively constant. In 1994, an elevated glucose concentration in May was restricted to males.

In 1993, the hepatic glucose concentrations in females of January and February differed from those of April and November and February values differed from those of May, July and October $(P<0 \cdot 05)$. In 1994, the differences between the sampling times were not significant.

In males of 1993, the February value differed from those of April, July, August, October and November. The glucose concentration of January was significantly higher than that of October. In 1994, significant differences existed between May and January, February, March and November, respectively. Differences between the sexes were significant only in May of both years $(P<0 \cdot 01$, U-test $)$.

\section{GLYCOGEN}

In contrast to glucose, the sine fitting to glycogen concentrations was significant [Fig. 6(b)], although high short-term variations were found during the first months of 1993 for both variables. 

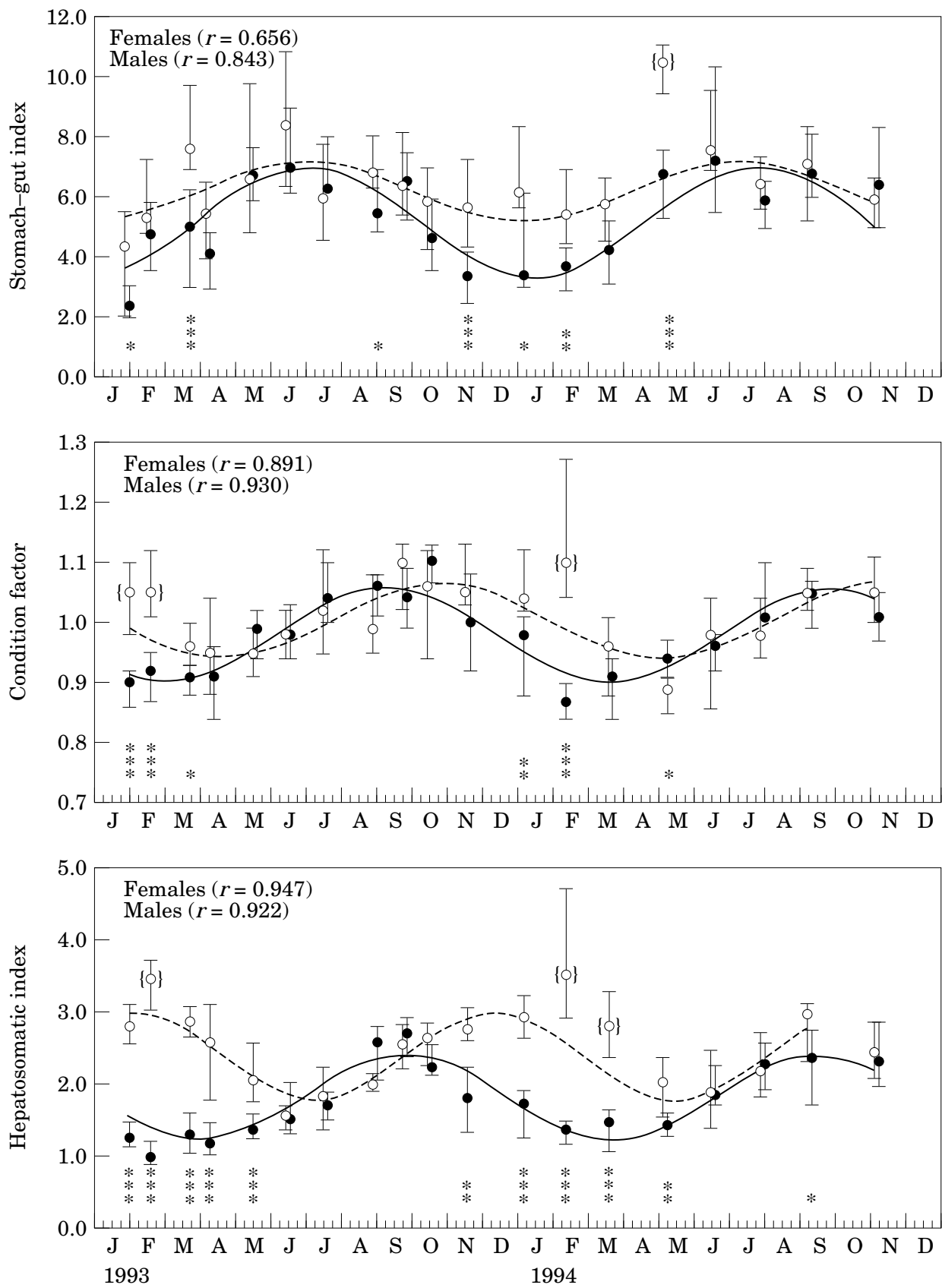

Month

FIG. 5. Stomach-gut index (SGI), condition factor (CF) and hepatosomatic index (HSI) of male ( $)$ and female $(\bigcirc)$ dab (median, 1.Q, 3.Q, $n=6-13$ ). Asterisks indicate significant differences between the sexes of the respective sampling time $(* P<0 \cdot 05 ; * * P<0 \cdot 01 ; * * * P<0 \cdot 001)$. Bracketed data were excluded from the sine curve fitting. 

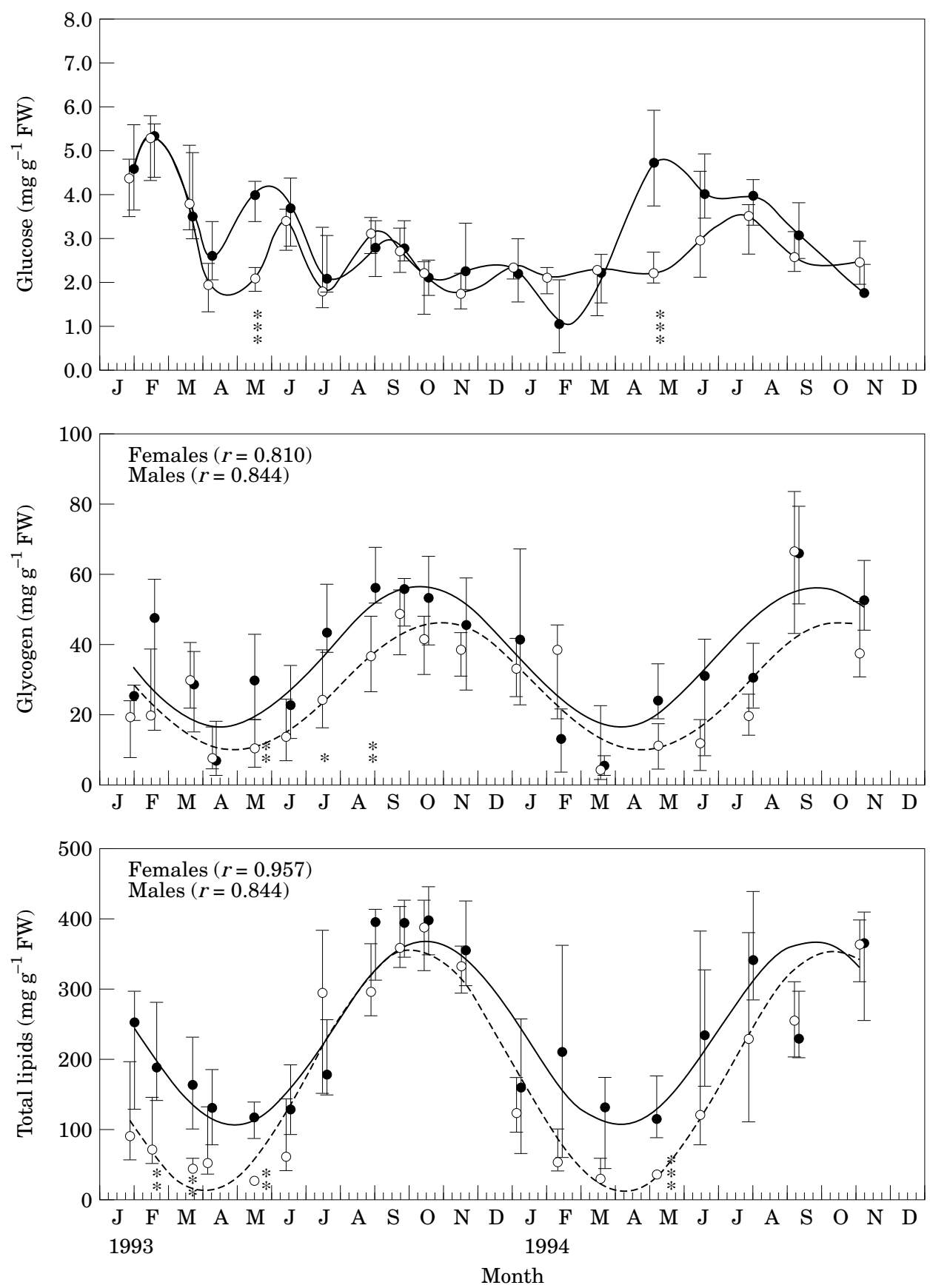

FIG. 6. Glucose, glycogen and lipid concentration in the liver of male $(\bullet)$ and female $(\bigcirc)$ dab (median, 1.Q, 3.Q, $n=6-13)$. Asterisks indicate significant differences between the sexes at the respective sampling time $(* P<0 \cdot 05 ; * * P<0 \cdot 01 ; * * * P<0 \cdot 001)$. 
In females, the highest values of $40-45 \mathrm{mg} \mathrm{g}^{-1} \mathrm{FW}$ were determined in autumn (October/November) and lowest amounts of about $10 \mathrm{mg} \mathrm{g}^{-1} \mathrm{FW}$ appeared in spring (April/May). In 1993, the glycogen concentrations of September differed from those of January, April, May and June. Furthermore, October and November values differed from April and May. In 1994, the values of September and November differed from March, May and June and September differed from July $(P<0 \cdot 05)$.

In males, the highest values were determined in early autumn (September/ October) and ranged from 50 to $60 \mathrm{mg} \mathrm{g}^{-1} \mathrm{FW}$. The lowest values below $20 \mathrm{mg} \mathrm{g}^{-1}$ FW were found in February to March. In 1993, glycogen concentrations of April differed from July, August, September, October and November. In 1994, September-values differed from February and March $(P<0 \cdot 05)$.

The amplitude of the sine curve calculated varied from $9 \cdot 7$ to $46 \cdot 1 \mathrm{mg} \mathrm{g}^{-1} \mathrm{FW}$ in females and $16 \cdot 5-56 \cdot 3 \mathrm{mg} \mathrm{g} \mathrm{g}^{-1} \mathrm{FW}$ in males. The spans between the maximum and the minimum were almost identical in both sexes (36.4 in females, $39 \cdot 8$ in males). Although the baseline was distinctly lower in females (27.9 v. $36 \cdot 4$ ), the difference was not considered significant, since the $95 \%$ CI confidence intervals of the fits overlapped. A slight phase-shift of 3-4 weeks was found between the sexes. Only few significant differences appeared between the sexes during the summer of $1993(P<0 \cdot 05$, U-test $)$.

\section{TOTAL LIPIDS}

The amount of total lipids in the liver could be described also by a sine function [Fig. 6(c)]. In females, highest amounts reached approximately $380 \mathrm{mg}$ $\mathrm{g}^{-1} \mathrm{FW}$ in September/October. The lowest lipid concentrations appeared in March and April and were less than $50 \mathrm{mg} \mathrm{g}^{-1} \mathrm{FW}$. In 1993, lipid concentrations of September and October differed from those of January, February, March, April and May. The values of August and November differed from March, April and May.

In males, maximal values were similar to those of the females and also appeared at similar times. The lowest values ranged from 100 to $150 \mathrm{mg} \mathrm{g}^{-1}$ FW and were found in spring. In 1993, values of August to November differed from those of April to June. October values differed from those of January to March. In 1994, glycogen concentrations of July and November differed from March and May.

The calculated curve varied from 12.6 to $353.5 \mathrm{mg} \mathrm{g}^{-1} \mathrm{FW}$ in females and $105.9-367.9 \mathrm{mg} \mathrm{g}^{-1} \mathrm{FW}$ in males and the spans were $340.9 \mathrm{mg} \mathrm{g}^{-1} \mathrm{FW}$ in females and $262.0 \mathrm{mg} \mathrm{g}^{-1} \mathrm{FW}$ in males. The baseline in females was $183.0 \mathrm{mg}$ $\mathrm{g}^{-1} \mathrm{FW}$ and differed significantly from the male baseline $\left(236.9 \mathrm{mg} \mathrm{g}^{-1} \mathrm{FW}\right)$.

\section{MUSCLE LIPID CONCENTRATIONS}

In contrast to the liver, no distinct seasonal variations were evident in muscle total lipids in either sex $(P>0 \cdot 05)$, although the lipid concentrations were slightly higher in September than in May and March. Furthermore, the values were also much lower than in the liver, ranging from 5.1 to $6.6 \mathrm{mg} \mathrm{g}^{-1} \mathrm{FW}$ (Table III). In general, females had slightly higher lipid concentrations than males, but the differences between the sexes were not significant. 
TABLE III. Concentrations of total lipids $\left[\mathrm{mg} \cdot \mathrm{g}^{-1} \mathrm{FW}\right]$ in muscle tissue of dab

\begin{tabular}{lccccccc}
\hline \multirow{2}{*}{$\begin{array}{l}\text { Date of } \\
\text { sampling }\end{array}$} & \multicolumn{3}{c}{ Females } & & \multicolumn{3}{c}{ Males } \\
\cline { 2 - 4 } \cline { 6 - 7 } & Median & 1.Q & 3.Q & & Median & 1.Q & 3.Q \\
\hline 7 May 1993 & $5 \cdot 76$ & $5 \cdot 37$ & $6 \cdot 54$ & & $5 \cdot 10$ & $4 \cdot 69$ & $6 \cdot 02$ \\
22 Sep. 1993 & $6 \cdot 58$ & $6 \cdot 23$ & $7 \cdot 37$ & & $6 \cdot 41$ & $5 \cdot 80$ & $6 \cdot 77$ \\
17 Mar. 1994 & $5 \cdot 94$ & $5 \cdot 20$ & $6 \cdot 96$ & & $5 \cdot 20$ & $4 \cdot 33$ & $5 \cdot 65$ \\
\hline
\end{tabular}

TABLE IV. Concomitance of nutritive parameters between females and males expressed by the rank correlation coefficient $\left(r_{s}, n=19\right)$

\begin{tabular}{lcr}
\hline Parameter & Abbreviation & \multicolumn{1}{c}{$r_{s}$} \\
\hline Stomach content & SC & $0 \cdot 509$ \\
\% of empty stomachs & $\%$ ES & $0 \cdot 484$ \\
Stomach-gut index & SGI & $0 \cdot 780$ \\
Condition factor & CF & $0 \cdot 275$ \\
Hepatosomatic index & HSI & $-0 \cdot 182$ \\
Glucose & Glu & $0 \cdot 572$ \\
Glycogen & Gly & $0 \cdot 740$ \\
Lipid & Lip & $0 \cdot 880$ \\
& & \\
\hline
\end{tabular}

\section{CONCOMITANCE OF NUTRITIVE PARAMETERS BETWEEN MALES AND FEMALES}

In order to investigate whether or not the seasonal course of each parameter was similar for both sexes or a distinct phase shift appeared, a rank correlation was performed on the medians of the monthly observations. A weak positive correlation $\left(r_{s}=0 \cdot 5-0 \cdot 6\right)$ was evident in the stomach content and the glucose concentration (Table IV), while glycogen was correlated more strongly. A high correlation $\left(r_{s}>0.75\right)$ was found in the SGI and the lipid concentration.

\section{CONCOMITANCE BETWEEN THE NUTRITIVE PARAMETERS WITHIN EACH SEX}

In females, the stomach content was inversely correlated with the percentage of empty stomachs and the SGI was inversely correlated with the HSI (Table V). A high positive correlation existed between the biochemical storage product glycogen and the condition factor as well as between lipid and the CF. A high correlation was also evident between the storage product glycogen and total lipids. No correlation was evident between the HSI and the storage products.

In males, the stomach content was inversely correlated with the $\% \mathrm{ES}$ also, but positively correlated with the SGI and CF and the HSI. The SGI, however, was not correlated with the somatic indices CF and HSI, nor with the concentrations of the biochemical storage products. In contrast to females, a high correlation 
TABLE V. Concomitance between somatic and biochemical nutritive parameters in female and male dab expressed by the rank correlation coefficient $\left(r_{s}, n=19\right)$

\begin{tabular}{|c|c|c|c|c|c|c|c|}
\hline & $\% \mathrm{ES}$ & SGI & $\mathrm{CF}$ & HSI & Glu & Gly & Lip \\
\hline \multicolumn{8}{|l|}{ Females } \\
\hline $\mathrm{SC}$ & -0.648 & $0 \cdot 346$ & $-0 \cdot 103$ & -0.322 & $0 \cdot 290$ & $-0 \cdot 167$ & -0.037 \\
\hline$\% \mathrm{ES}$ & - & $-0 \cdot 123$ & $-0 \cdot 245$ & $0 \cdot 142$ & -0.508 & $-0 \cdot 149$ & $-0 \cdot 369$ \\
\hline SGI & - & - & -0.488 & -0.532 & $0 \cdot 179$ & -0.081 & $-0 \cdot 158$ \\
\hline $\mathrm{Cf}$ & - & - & - & $0 \cdot 429$ & $0 \cdot 058$ & $0 \cdot 830$ & $0 \cdot 700$ \\
\hline HSI & - & - & - & - & $0 \cdot 082$ & $0 \cdot 349$ & -0.095 \\
\hline Glu & - & - & - & - & - & -0.012 & -0.019 \\
\hline Gly & - & - & - & - & - & - & $0 \cdot 740$ \\
\hline \multicolumn{8}{|l|}{ Males } \\
\hline $\mathrm{SC}$ & $-0 \cdot 840$ & $0 \cdot 659$ & 0.587 & $0 \cdot 370$ & $0 \cdot 243$ & $0 \cdot 278$ & $0 \cdot 074$ \\
\hline$\% \mathrm{ES}$ & - & $-0 \cdot 614$ & -0.584 & -0.386 & $-0 \cdot 216$ & -0.297 & $-0 \cdot 230$ \\
\hline SGI & - & - & $-0 \cdot 379$ & $-0 \cdot 347$ & $0 \cdot 343$ & $0 \cdot 198$ & $-0 \cdot 156$ \\
\hline $\mathrm{Cf}$ & - & - & - & $0 \cdot 820$ & -0.223 & 0.830 & 0.537 \\
\hline HSI & - & - & - & - & $-0 \cdot 216$ & $0 \cdot 830$ & $0 \cdot 710$ \\
\hline Glu & - & - & - & - & - & $-0 \cdot 100$ & $-0 \cdot 288$ \\
\hline Gly & - & - & - & - & - & - & $0 \cdot 700$ \\
\hline
\end{tabular}

Abbreviations as in Table IV.

existed between the HSI and glycogen and glucose, respectively. Similar to females, glycogen and lipid concentrations were highly correlated.

\section{CORRELATION BETWEEN THE HSI AND TOTAL LIPIDS}

In male dab, the HSI was linearly correlated with the lipid concentration $(P<0 \cdot 001)$. In females, however, no significant correlation was found when all values of the investigated period were considered (Fig. 7). The pattern of females could be described best as a circle (not shown in Fig. 7). From June to December the course was similar to that of males. In December/January the lipid concentration decreased rapidly while a high HSI was maintained. In the following months the HSI also decreased towards lowest values in May. In order to simplify the calculation, separate linear regressions were fitted, representing the periods June-December $(P<0.05)$ and January-May, respectively. However, the latter regression was not significant. Similar results were obtained when the HSI was calculated in relation to the total weight.

\section{DISCUSSION}

The stomach volume of dab is proportional to body weight (Jobling et al., 1977). Stomachs can contain considerable amounts of food due to the elasticity of the organ. Occasionally we found $12-15 \mathrm{~g}$ of content which filled the dilatable stomach totally. In such cases, the food always consisted of large pieces of fish or fish carrion. This also explains the relatively large variation in Fig. 1. In general, however, smaller amounts of food were present and these amounts corresponded well with recent data reported by Temming \& Hammer (1994). The stomach contents of females did not show a distinct seasonal cycle as in males, indicating a more active and continuous feeding behaviour throughout 


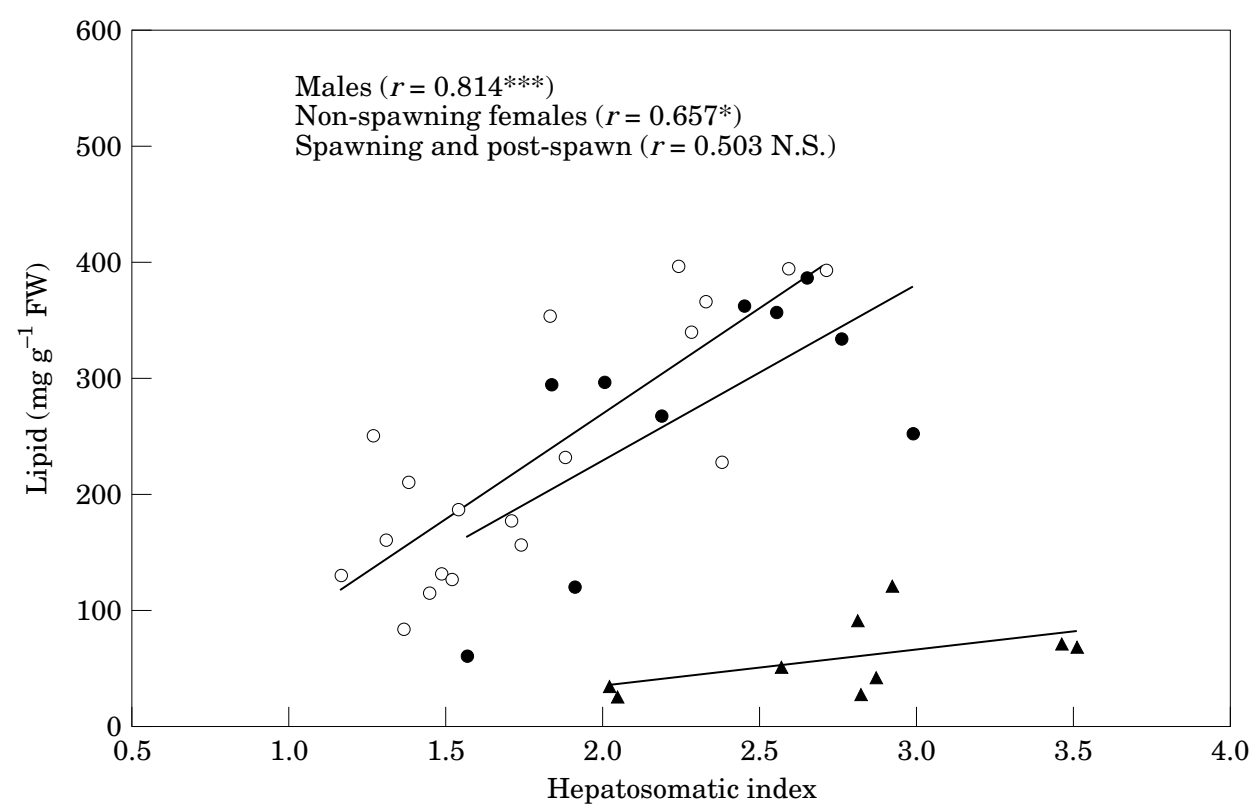

FIG. 7. Correlation between the hepatosomatic index and the lipid concentration in the liver in male and female dab. The correlation coefficients are included in the figure and significance levels are indicated by asterisks. $\bigcirc$, Males; $\boldsymbol{\bullet}$, non-spawning females; $\boldsymbol{\Lambda}$, spawning and post-spawning females.

the year. This different feeding behaviour was reflected also by the lower number of empty stomachs in females during the winter. Generally, the percentage of empty stomachs was higher in males than in females.

Dab do not prefer a specific diet and thus the food ingested often reflects the typical benthic epi-fauna in the respective region (Franz, 1910; Kühl, 1963). In the present study, ophiuroids were the main food organism at Helgoland and often represented the only diet. They were ingested by both sexes in a proportional amount. Polychaetes were often numerous also, while molluscs and crustaceans were less frequent. Occasionally, echinoids formed a significant part of the stomach content. The relative high negative correlation of ingested crustaceans between the sexes reflected differences between the 2 years of observation since seasonal variations within each of the years were not observed (see Fig. 4).

The stomach content is an indicator for recently ingested food. Since dab have high stomach emptying rates (Fletcher et al., 1984), a value including the total gut content might describe better the feeding activity over a longer period prior to catch. The seasonal course of the SGI with its maximum in mid-summer corresponded well with the stomach content, which indicated that the dab were feeding continuously. Although the stomach content was considerably lower in males than in females, the body weight-normalized SGIs were similar during summer. Similar to the stomach content, seasonal variations were more distinct in males than in females. During the winter season, the SGI of males was lower than that of females, reflecting the reduced but not suspended feeding activity. 
The feeding rate and thus the nutritive state, is reflected by the condition factor. In both sexes, a phase-shift between the maximum $\mathrm{CF}$ and the stomach content and SGI, respectively, appeared. In males, the maximum CF followed with a delay of about 2 months, while the maximum in females appeared 4 months later. The resulting phase shift of 2 months between the sexes corresponded at least to the reproductive cycle, i.e. the maturation and growth of the gonads. Gonad maturation starts in autumn and continues until the beginning of the spawning period in February-March (Htun-Han, 1978; Knust, 1987; own observations). The testes remain relatively small ( $2 \%$ of body weight) when developed and do not contribute significantly to the total body weight. In contrast, the weight of ovaries can reach $15-20 \%$ of the wet body weight and thus contributes a significant part of mass which is included in the calculation of CF. For comparison, $\mathrm{CF}$ was calculated also in relation to the carcass weight $\left(\mathrm{CF}_{\mathrm{c}}\right)$. No significant difference appeared between the courses of total-weight and carcass-weight-related $\mathrm{CFs}$ in males. The $\mathrm{CF}_{\mathrm{c}}$ of females still followed behind, but the phase shift was less distinct and amounted to 6 weeks instead of 8 weeks. In both sexes, the maximal summer/autumn-values were similar, while the winter/spring-minimum was lower in females than in males. This indicates that females use the comparatively higher food intake in winter entirely to meet the energy demand for gonad maturation.

With a rich food supply, nutrients are stored in the liver. Their amount can be expressed as the hepatosomatic index (HSI), which relates liver weight to body weight. In males, the seasonal course of the HSI corresponded well with that of the condition factor and reflected the feeding habits as described above. In females, however, liver weight increased until the winter season due to more continuous feeding. Highest HSI were reached shortly before and during the spawning period. In the winter of 1994, the values diverged strongly from the sine model. The results were similar, when the HSI was calculated in relation to the total weight instead of the carcass weight. Accordingly, an artefact due to the different calculation basis can be excluded.

The subsequent continuous decrease of the HSI in females may be related to the following factors: First, the decreasing food availability in the environment cannot meet the energy demand. Thus, storage products in the liver were liberated to fuel metabolic processes. Second, the maturing gonads need additional energy which cannot be supplied by feeding and must be obtained from the liver. Third, at the beginning of the spawning season, females feed less due to sexual activity. This was indicated also by the elevated number of empty stomachs in females during the spawning period. However, it cannot be decided yet which of the mentioned factors causes the sharp HSI decrease primarily. Presumably, each one contributes to a certain extent.

The predominant storage products in the fish liver are glycogen and lipids. The glycogen concentration reflected the annual feeding pattern and corresponded well with the CF. Lowest values $\left(<10 \mathrm{mg} \mathrm{g}^{-1} \mathrm{FW}\right)$ were found in early spring, while highest amounts were determined from late summer to early autumn (50-60 $\left.\mathrm{mg} \mathrm{g}^{-1} \mathrm{FW}\right)$. In the plaice Pleuronectes platessa L., glycogen amounts to about $5 \mathrm{mg} \mathrm{g}^{-1}$ liver (Wardle, 1972). This value corresponds to the lowest amounts that we found in dab. Petersen \& Korsgaard Emmersen (1977) found glycogen concentrations of $10-22 \mathrm{mg} \mathrm{g}^{-1}$ liver and 
maximal values of $46 \mathrm{mg} \mathrm{g}^{-1}$ liver in the flounder $P$. flesus L., which matched well with our results in dab. Concentrations of the same range $(3 \cdot 2-5 \cdot 2 \%=32-$ $52 \mathrm{mg} \mathrm{g}^{-1}$ ) were reported by Gill et al. (1983) in the catfish Heteropneustes fossilis (Bloch).

The seasonal variation of liver glycogen was similar in both sexes. However, during spring and summer, glycogen concentrations were higher in males than in females, indicating a higher significance as storage product in the former. These seasonal trends corresponded well with observations by Petersen \& KorsgaardEmmersen (1977) in P. flesus. Although the authors did not cover the entire seasonal cycle, glycogen values in late summer were distinctly higher than concentrations in autumn and winter. Seasonal changes of the glycogen concentrations in the livers of plaice P. platessa (Dawson \& Grimm, 1980) were of the same order of magnitude in dab. However, unlike dab, the highest relative amounts were found in May.

In contrast to glycogen, the amount of free glucose in the liver did not follow a distinct seasonal cycle and did not correspond with the concentration of glycogen, nor were distinct sexual differences evident. Remarkably, the glucose concentrations were highest in spring during the spawning season. Glycogen can be mobilized rapidly to meet metabolic demands. Thus, an elevated glucose concentration is likely to occur during periods of physical activity due to local migration, or generally increased metabolism during spawning time.

The main storage product in most fish species, however, are the lipids. We measured total lipids with the sulphophospho-vanillin method according to Zöllner \& Kirsch (1962). This method is well suited for total lipid determination, comparable with gravimetric methods (Barnes \& Blackstock, 1973), and allows the exact measurement of lipids in mg-quantities of tissue.

The significance of lipids as storage products became obvious in the seasonal course of lipid concentrations, ranging from $<50$ to $400 \mathrm{mg} \mathrm{g}^{-1}$. Given a sufficient food supply and increased feeding activity in late spring, a rapid increase of liver lipids was observed. At the end of the summer season, a corresponding sharp decrease was determined. The maximal summer concentrations were similar in both sexes, whereas the winter and spring values were distinctly lower in females. This difference could reflect the elevated nutrient requirements for ovary maturation compared to the maturation of the testis.

The significance of the liver as principal storage organ for lipids is supported by the relatively low lipid concentrations in the muscle tissue which could also serve as a lipid store (Dawson \& Grimm, 1980). Identical extraction-methods were applied to both tissues and therefore a direct comparison is possible. The lipid concentrations in the muscle reached only about $1 \%$ of the liver-values of summer animals. Furthermore, only slight seasonal changes were evident between winter and summer, indicating no distinct transfer of muscle lipids into other organs. However, it should be considered that the muscle tissue forms a much larger organ than the liver. Therefore, a possible transfer of lipids from the muscle into the ovaries may not necessarily lead to significant changes in muscle lipid concentration.

The comparison of nutritive parameters between the sexes by rank correlation analysis revealed highly concomitant courses of the SGI as well as of the glycogen and lipid concentrations but not in the case of the CF- and the 
HSI-values. The divergence of the CFs is related to the strong influence of gonad maturation in females (see above).

The HSI often serves as an index for the amount of stored lipids in the fish liver and therefore as an index for the nutritive state. In male dab, this relation is applicable throughout the season although high variability only allows a rough estimation of the lipid concentration. In females, however, a more complex relation betwen HSI and total lipid exists. Therefore, the estimation of the total lipid concentration via the HSI should be used carefully. The sharp lipid decrease at still elevated HSI can not be explained easily. Presumably, the lipid composition changed during final maturation to compounds which were less specifically detectable by the sulphophosphovanillin reaction, e.g. saturated fatty acids (Zöllner \& Kirsch, 1962). Parallel to lipid deposition, the amount of cell water might have increased and kept an elevated liver weight and thus a high HSI.

The storage of nutrients is not only related to the amount of ingested food but should also be reflected in the proximate composition of the prey. The biochemical composition of several benthic species of the North Sea was determined by early workers (Delff, 1912; Meyer, 1914; Struve \& Kairies, 1930). Lipid amounts were $0.67 \%$ in the ophiuroid Ophiura albida, $0.62-1 \cdot 20 \%$ DW in polychaetes and $8 \cdot 26 \%$ DW in the crustacean species Orchestia litorale. However, in comparison with recent results, these data seem to be underestimated, e.g. 10.3\% DW in juvenile ophiuroids Ophionotus hexactis (Turner, 1979), and $20.5 \%$ DW in the crustacean Jassa falcata (Nair \& Anger, 1980). The gross biochemistry of bivalve species was listed by Wenne \& Styczynska-Jurewicz (1987). The lipid concentrations ranged from 5\% DW in Abra alba to $20-30 \%$ in Macoma balthica. Somewhat lower lipid amounts were reported in polychaetes, e.g. $12 \cdot 5 \%$ DW in Nereis succinea (Neuhoff, 1979), and only approximately $1 \%$ FW in Nephthys spp. (Boon et al., 1985).

Taking into consideration the biochemical composition of prey organisms and the seasonal variation of food amounts in the intestines (SGI), the strong increase of liver lipids during late spring and early summer could not be explained solely by elevated feeding activity. Neither did dab show a distinct preference for lipid-rich organisms during the spring. It may be suggested that, beside the increase of feeding activity, an elevation of the food conversion rate contributed significantly to the progressing accumulation of lipids. As shown by Pandian (1970), conversion efficiency in mature dab of both sexes was highest at $8^{\circ} \mathrm{C}$, i.e the temperature of late spring. Furthermore, the optimal temperature for maximum conversion efficiency was lower than the temperatures of maximal food intake. Accordingly, these physiological properties allow the dab to utilize food efficiently in the early season and therefore also enable the rapid increase of liver lipids.

Concerning the bio-concentration of lipophilic toxins, Hilton et al. (1983) demonstrated in rainbow trout Oncorhynchus mykiss (Walbaum) that organic contaminants are accumulated proportionally to their dietary levels. The relatively high lipid concentration in bivalves and their feeding behaviour (filter or suspension feeders) identifies this group as predominant in the accumulation of pollutants. This suggestion agrees with results of Loizeau (1992) who reported high PCB concentrations in molluscs. Crustaceans were also 
characterized by high PCB loads, which related to their feeding habits as necrophages and detrivores. Annelids and echinoderms were less contaminated. In this respect, the flux of toxins along the trophic chain and their concentrations in dab tissues should not only be related to the toxin concentration in the environment (e.g. the sediment), but should also depend on the predominant prey and the susceptibility of prey organisms to accumulate toxins.

The present study demonstrated the significance of lipid metabolism in dab during the annual cycle and confirmed the liver as principal storage site.

Although the feeding habits of dab are well investigated, little is known about the biochemical composition of the food organisms and the ability of dab to convert the prey. Therefore, future studies are required to investigate the significance of particular species, e.g. ophiuroids, in the contribution to storage products in dab and in other benthic fish species.

Ms Marion Ziebarth, Mr Gerrit Sahling and Mr Erich Harms supplied technical assistance. Dr R.-A. Vetter was helpful in the statistical analysis. Dr U. Damm gave constructive comment on the manuscript. We thank also the crews of the research vessels FS ' Heincke' and especially FK ' Uthörn' for efficient work in the field. This work was supported by a scholarship from the Biologische Anstalt Helgoland to the first author.

\section{References}

Arntz, W. E. (1971). Die Nahrung der Kliesche (Limanda limanda [L.]) in der Kieler Bucht. Berichte der Deutschen Wissenschaftlichen Kommission für Meeresforschung 22, 129-183.

Barnes, H. \& Blackstock, J. (1973). Estimation of lipids in marine animals and tissues: Detailed investigation of the sulphophosphovanillin method for 'total' lipids. Journal of Experimental Marine Biology and Ecology 12, 103-118.

Bohl, H. (1957). Die Biologie der Kliesche (Limanda limanda L.) in der Nordsee. Berichte der Deutschen Wissenschaftlichen Kommission für Meeresforschung 15, $1-57$.

Boon, J. P., van Zantvoort, M. B. \& Govaert, M. J. M. A. (1985). Organochlorines in benthic polychaetes (Nephthys sp.) and sediment from the southern North Sea. Identification of individual PCB components. Netherlands Journal of Sea Research 19, 93-109.

Büther, H. (1990). Spatial and temporal trend in organochlorine concentration of dab (Limanda limanda) and flounder (Platichthys flesus) in the North Sea. Archiv für Fischereiwissenschaft 40, 133-152.

Daan, N., Bromley, P. J., Hislop, J. R.G. \& Nielsen, N. A. (1990). Ecology of North Sea fish. Netherlands Journal of Sea Research 26, 343-386.

Dawson, A. S. \& Grimm, A. S. (1980). Quantitative seasonal changes in the protein, lipid and energy content of the carcass, ovaries and liver of adult female plaice, Pleuronectes platessa L. Journal of Fish Biology 16, 493-504.

Dethlefsen, V. \& Huschenbeth, E. (1986). Regional differences in organochlorine residues in livers of dab (Limanda limanda) and plaice (Pleuronectes platessa) of the southern North Sea. Archiv für Fischereiwissenschaft 37, 25-42.

Delff, C. (1912). Beiträge zur Kenntnis der chemischen Zusammensetzung wirbelloser Meerestiere. Wissenschaftliche Meeresuntersuchungen, Neue Folge, Abteilung Kiel 14, 51-82.

Fletcher, D. J., Grove, D. J., Basimi, R. A. \& Ghaddaf, A. (1984). Emptying rates of single and double meals of different food quality from the stomach of the dab, Limanda limanda (L.). Journal of Fish Biology 25, 435-444.

Franz, V. (1910). Ueber die Ernährungsweise einiger Nordseefische, besonders der Scholle. Wissenschaftliche Meeresuntersuchungen, Neue Folge, Abteilung Helgoland 9, 197-215. 
Gill, T. S., Mehrotra, N. \& Khanna, N. (1983). Circannual rhythmicity in blood glucose, cholesterol and hepatic glycogen in a catfish, Heteropneustes fossilis (Bloch). Comparative Physiology and Ecology 8, 349-353.

Hilton, J. W., Hodson, P. V., Braun, H. E., Leatherland, J. L. \& Slinger, S. J. (1983). Contaminant accumulation and physiological response in rainbow trout (Salmo gairdneri) reared on naturally contaminated diets. Canadian Journal of Fisheries and Aquatic Sciences 40, 1987-1994.

Htun-Han, M. (1978). The reproductive biology of the dab Limanda limanda (L.) in the North Sea: Gonosomatic index, hepatosomatic index and condition factor. Journal of Fish Biology 13, 369-378.

Jobling, M., Gwyther, D. \& Grove, D. J. (1977). Some effects of temperature, meal size and body weight on gastric evacuation time in the dab, Limanda limanda (L.). Journal of Fish Biology 10, 291-298.

Kammann, U., Knickmeyer, R. \& Steinhart, H. (1990). Distribution of polychlorobiphenyls and hexachlorbenzene in different tissues of the dab (Limanda limanda L.) in relation to lipid polarity. Bulletin of Environmental Contamination and Toxicology 45, 552-559.

Keppler, D. \& Decker, K. (1984). Glycogen. In Methods of Enzymatic Analysis 3rd edn., Vol. VI (Bergmeier, H. U., ed.), pp. 11-18. Weinheim: Verlag Chemie.

Knickmeyer, R. \& Steinhart, H. (1989). On the distribution of polychlorinated biphenyl congeners and hexachlorbenzene in different tissues of dab (Limanda limanda) from the North Sea. Chemosphere 19, 1309-1320.

Knust, R. (1987). Nahrung, Kondition und Gonadengewicht von Klieschen (Limanda limanda) der Deutschen Bucht und der Doggerbank. Informationen für die Fischwirtschaft 34, 161-165.

Koprivnjak, J.-F., Lum, K. R., Sisak, M. M. \& Saborowski, R. (1996). Determination of $a-, \gamma(+\beta)$-, and $\delta$-tocopherols in a variety of liver tissues by reverse-phase high pressure liquid chromatography. Comparative Biochemistry and Physiology 113B, 143-148.

Kühl, H. (1963). Über die Nahrung der Scharbe (Limanda limanda L.). Archiv für Fischereiwissenschaft 14, 8-17.

Kunst, A., Draeger, B. \& Ziegenhorn, J. (1984). D-glucose. UV-method with hexokinase and glucose-6-phosphate dehydrogenase. In Methods of Enzymatic Analysis 3rd ed., Vol. VI (Bergmeier, H. U., ed.), pp. 163-172. Weinheim: Verlag Chemie.

Lienert, G. A. (1978). Verteilungsfreie Methoden in der Biostatistik, Bd. II. Meisenheim am Glan: Verlag Anton Hain.

Loizeau, V. (1992). Distribution des PCB dans la limande et les espèces benthiques de la Baie de Seine. Journal de Recherche Oceanographique 17, 61-67.

Lozán, J. L. (1988). Verbreitung, Dichte und Struktur der Population der Klieschen (Limanda limanda L.) in der Nordsee mit Vergleichen zu den Populationen um Island und in der Ostsee anhand meristischer Merkmale. Archiv für Fischereiwissenschaft 38, 165-189.

Meyer, J. A. (1914). Beiträge zur Kenntnis der chemischen Zusammensetzung wirbelloser Tiere. Wissenschaftliche Meeresuntersuchungen, Neue Folge, Abteilung Kiel 16, 231-282.

Nair, K. K. C. \& Anger, K. (1980). Seasonal variations in the population structure and biochemical composition of Jassa falcata (Crustacea, Amphipoda) off the island of Helgoland (North Sea). Estuarine and Coastal Marine Science 11, 505-513.

Neuhoff, H.-G. (1979). Effects of seasonally varying factors on a Nereis succinea population (Polychaeta, Annelida). Marine Ecology Progress Series 1, 263-268.

Pandian, T. J. 1970. Intake and conversion of food in the fish Limanda limanda exposed to different temperatures. Marine Biology 5, 1-17.

Petersen, I. M. \& Korsgaard Emmerson, B. (1977). Changes in serum glucose and lipids, and liver glycogen and phosphorylase during vitellogenesis in nature in the flounder (Platichthys flesus L.). Comparative Biochemistry and Physiology 58B, $167-171$. 
Saborowski, R. \& Buchholz, F. (1996). Some observations on the seasonal distribution of dab, Limanda limanda, in the southern North Sea. Helgoländer Meeresuntersuchungen (in press).

Sachs, L. (1984). Angewandte Statistik. Berlin: Springer.

Sokal, R. R. \& Rohlfs, F. J. (1995a). Biometry. New York: W. H. Freeman.

Sokal, R. R. \& Rohlfs, F. J. (1995b). Statistical tables. New York: W. H. Freeman.

Stebbing, A. R. D., Dethlefsen, V., Addison, R. F., Carr, M., Chapman, P. M., Cofino, W. P., Heip, C., Karbe, L., Moore, M. N. \& Vethaak, A. D. (1992). Overall summary and some conclusions from the Bremerhaven workshop. Marine Ecology Progress Series 91, 323-329.

Struve, K. \& Kairies, W. (1930). Die chemische Zusammensetzung einiger als Fischnahrung wichtiger wirbelloser Bodentiere der Nordsee. Wissenschaftliche Meeresuntersuchungen, Neue Folge, Abteilung Helgoland 17, 22.

Temming, A. \& Hammer, C. (1994). Sex specific food consumption of dab (Limanda limanda L.) based on a $24 \mathrm{~h}$ fishery. Archives of Fishery and Marine Research 42, 123-136.

Turner, R. L. (1979). Organic and inorganic composition of post-metamorphic growth stages of Ophionotus hexactis (E. A. Smith) (Echinodermata, Ophiuroidae) during intraovarian incubation. Journal of Experimental Marine Biology and Ecology 36, $41-51$.

Wardle, C. S. (1972). The changes in blood glucose in Pleuronectes platessa following capture from the wild: a stress reaction. Journal of the Marine Biological Association of the United Kingdom 52, 635-651.

Wenne, R. \& Styczynska-Jurewicz, E. (1987). Gross biochemical composition of the bivalve Macoma balthica from the Gulf of Gdansk (Southern Baltic). Marine Biology 96, 73-78.

Zöllner, N. \& Kirsch, K. (1962). Über die quantitative Bestimmung von Lipoiden (Mikromethode) mittels der vielen natürlichen Lipoiden (allen bekannten Plasmalipoiden) gemeinsamen Sulfophosphovanillin-Reaktion. Zeitschrift für die gesamte Experimentelle Medizin 135, 545-561. 